Jurnal ECOTIPE, Vol. 7, No.2, Oktober 2020, Hal. 78-84

p-ISSN 2355-5068, e-ISSN 2622-4852

Akreditasi Kemenristekdikti (SINTA 4), SK. No.10/E/KPT/2019

DOI: 10.33019/jurnalecotipe.v7i2.1887

\title{
Perancangan Sistem Optimasi Smart Solar Electrical pada Pembangkit Listrik Tenaga Surya (PLTS) dengan Metode Tracking Dual Axis Technology
}

\author{
Rean Khotama ${ }^{1}$, Dian Budhi Santoso ${ }^{2}$, Arnisa Stefanie ${ }^{3}$ \\ Program Studi Teknik Elektro, Universitas Singaperbangsa Karawang ${ }^{1}$ \\ Program Studi Teknik Elektro, Universitas Singaperbangsa Karawang ${ }^{2}$ \\ Program Studi Teknik Elektro, Universitas Singaperbangsa Karawang ${ }^{3}$ \\ *rean.khotama16118@student.unsika.ac.id ${ }^{1}$,dian.budhi@ft.unsika.ac.id², arnisa.stefanie@staff.unsika.ac.id ${ }^{3}$
}

\begin{abstract}
The Solar Power Plant is an environmentally friendly, and Indonesia is a tropical country that gets an average of $4.8 \mathrm{kWh}$ of solar light per day. However, in general, the type of solar panel installation is carried out regularly (statistically) at a certain angle so that the solar radiation absorbed by the solar panels is not optimal when the sun turns its back on the solar panel. This study aims to design a site that can optimally absorb sunlight rays using the Tracking Dual Axis Technology method based on the ATmega 2560 microcontroller as a system controller and Light Dependent Resistor (LDR) as a sun tracking sensor. So that it can maximize the absorption of solar radiation by solar panels. The Dual Axis Technology Tracking testers get a maximum Photovoltac voltage of 20.99 volts and a minimum of 19.75 volts and a maximum current of 21.04 mA and a minimum of $14.12 \mathrm{~mA}$. Meanwhile, for testing solar panels with a fixed (static) position, the maximum voltage generated by the solar panels is 19.99 volts and a minimum of 18.3 volts and a maximum current of $18.3 \mathrm{~mA}$ and a minimum of $13.72 \mathrm{~mA}$.
\end{abstract}

Keywords : Light Dependent Resistor (LDR), Mikrokontroller ATmega 2560, Solar cell, Tracking Dual Axis

\section{INTISARI}

Pembangkit Listrik Tenaga Surya (PLTS) merupakan pembangkit listrik yang ramah lingkungan, dan Indonesia merupakan negara tropis yang mendapatkan pencahayaan sinar matahari optimum rata - rata $4,8 \mathrm{kWh}$ per hari. Namun pada umumnya jenis pemasangan panel surya dilakukan secara tetap (statis) pada sudut tertentu sehingga radiasi matahari yang diserap oleh panel surya menjadi tidak optimal pada saat matahari membelakangi panel surya. Penelitian ini bertujuan untuk merancang suatu sitem yang mampu menyerap pancaran sinar matahari secara optimum dengan menggunakan metode Tracking Dual Axis Technology Berbasis mikrokontroller ATmega 2560 sebagai pengendali Sistem dan Light Dependent Resistor (LDR) Sebagai sensor pelacak matahari. Sehingga dapat memaksimalkan penyerapan radiasi matahari oleh panel surya. Untuk pengujian Tracking Dual Axis Technology di dapatkan tegangan maksimum yang dihasilkan panel surya sebesar 20,99 Volt dan minimum 19,75 Volt serta arus maksimum sebesar 21,04 mA dan minimum 14,12 mA. Sementara untuk pengujian panel surya dengan posisi tetap (statis) di dapatkan tegangan maksimum yang dihasilkan panel surya sebesar 19,99 Volt dan minimum 18,3 Volt serta arus maksimum sebesar 18,3 mA dan minimum 13,72 $\mathrm{mA}$.

Kata kunci: Light Dependent Resistor (LDR), Mikrokontroller ATmega 2560, Panel Surya, Tracking Dual Axis

\section{PENDAHULUAN}

Perkembangan teknologi dan pertumbuhan penduduk yang sangat pesat, begitu juga dengan kebutuhan energi listrik yang semakin meningkat [1]. Indonesia memiliki potensi energi baru terbarukan cukup melimpah. Salah satunya adalah energi surya yang di konversi menjadi energi listrik menggunakan sel surya. Pada hal ini Indonesia memiliki Incoming Solar Radiation (Insolasi) matahari rata - rata 4,8 $\mathrm{kWh} / \mathrm{m} 2$ per hari [2]. Besarnya Insolasi tersebut memiliki rincian di Indonesia bagian timur sebesar 5,1 $\mathrm{kWh} / \mathrm{m} 2$ per hari dan dibagian barat $4,5 \mathrm{kWh} / \mathrm{m} 2$ per hari [2]. Hal ini perlu diupayakan untuk menjadi sumber energi alternatif pengganti energi fosil yang 
mendominasi sebagian besar produksi listrik Negara. Tercatat dalam data Kementrian Energi Sumber Daya Mineral bahwa energi fosil menyuplai $41,15 \%$ produksi listrik Negara [3].

Listrik yang bersumber dari energi matahari saat ini masih banyak belum dikembangkan meskipun kita mempunyai potensi yang cukup besar. Oleh karena itu pengembangan Pembangkit Listrik Tenaga Surya (PLTS) sebaiknya dikembangkan di Indonesia untuk mecukupi kebutuhan masyarakat.

Umumnya panel surya diletakkan dengan posisi tetap pada dudukan nya (statis), teknik pemasangan panel surya seperti ini memiliki kerugian yaitu pada saat matahari bergerak membelakangi panel Solar Photovoltaic (SPV), energi yang diproduksi panel SPV akan menurun [4]. Menyebabkan posisi panel surya tidak berada dalam posisi yang tepat terhadap arah datang cahaya matahari. Karena berdasakan rotasi bumi, maka posisi matahari tidak selalu sama setiap saat. Akibat nya, panel surya tidak mampu menyerap energi matahari secara maksimal karena perubahan posisi matahari disetiap waktunya [5]. Berdasarkan masalah tersebut untuk mendapatkan efisiensi maksimum, maka panel surya harus mengikuti pergerakan matahari sehingga tidak ada sudut deviasi antara matahari dan panel surya atau sinar matahari jatuh tegak lurus ke panel surya.

Pada penelitian ini, PLTS yang dibuat memungkinkan solar cell mengikuti pergerakan arah datangnya matahari dengan menggunakan metode Tracking dual axis technology. Solar tracking system dengan memanfaatkan dua sumbu pergerakan, merupakan sistem penjejakan posisi matahari yang memungkinkan panel surya mengikuti posisi matahari kesegala arah di setiap waktu. Dalam hal ini, data arus dan tegangan yang dihasilkan panel surya akan direkam langsung ke mikroSD menggunakan data logger. Solar tracking system ini dikendalikan secara otomatis dengan Mikrokontroler ATMega 2560 melalui motor stepper Nema23 dan Aktuator linear dengan Light Dependent Resistor (LDR) sebagai sensor cahaya. Teknologi ini dapat meningkatkan kapabilitas panel surya untuk menyerap energi surya secara optimal.

\section{LANDASAN TEORI}

\section{A. Panel Surya}

Sel surya atau Solar Cell adalah suatau perangkat atau komponen yang dapat mengubah energi cahaya matahari menjadi enrgi listrik dengan menggunakan prinsip efek Photovoltaic. Yang dimaksud dengan efek Photovoltaic adalah suatu fenomena dimana munculnya tegangan listrik karena adanya hubungan atau kontak dua elektroda yang dihubungkan dengan sistem padatan atau cairan saat mendapatkan energi cahaya. Oleh karena itu, sel surya atau solar cell disebut juga dengan photovoltaic oleh Hendri Becquerel, 1839.

\section{B. Solar Tracker}

Kebanyakan panel surya dipasang permanen dengan sudut elevasi yang tetap (fixed elevating angles). Hal ini menyebabkan panel surya tersebut tidak dapat menyerap radiasi matahari secara optimal karena matahari selalu bergerak, yaitu dalam arah timur-barat (disebut gerak semu harian matahari) dan utara-selatan (disebut gerak semu tahunan matahari). Penyerapan radiasi matahari akan optimal jika arah radiasi matahari tegak lurus terhadap permukaan bidang panel surya. Oleh sebab itu, diperlukan upaya untuk mengarahkan permukaan panel surya agar selalu tegak lurus terhadap cahaya matahari. Metode untuk mengarahkan panel surya agar selalu mengikuti arah gerak matahari itu dikenal sebagai metode penjejakan arah gerak matahari (the method of tracking the sun) [6]. Alat yang digunakan untuk mengikuti arah gerak matahari dikenal sebagai solar tracker. Arah gerak matahari tersebut dapat diikuti dengan mengindera perubahan arah cahaya yang dipancarkannya.

Solar tracker adalah perangkat yang mengorientasikan muatan kearah matahari. Muatan nya dapat berupa panel photovoltaic (panel surya), reflector, lensa, atau perangkat optik lainnya. Dalam aplikasi panel surya layar datar, solar tracker digunakan untuk meminimalkan sudut insiden (i) antara sinar matahari yang masuk dalam panel surya. Hal ini dapat meningkatkan jumlah energi listrik yang dihasilkan sebuah pembangkit listrik tenaga surya. 
Jurnal ECOTIPE, Vol. 7, No.2, Oktober 2020, Hal. 78-84

p-ISSN 2355-5068, e-ISSN 2622-4852

Akreditasi Kemenristekdikti (SINTA 4), SK. No.10/E/KPT/2019

DOI: 10.33019/jurnalecotipe.v7i2.1887

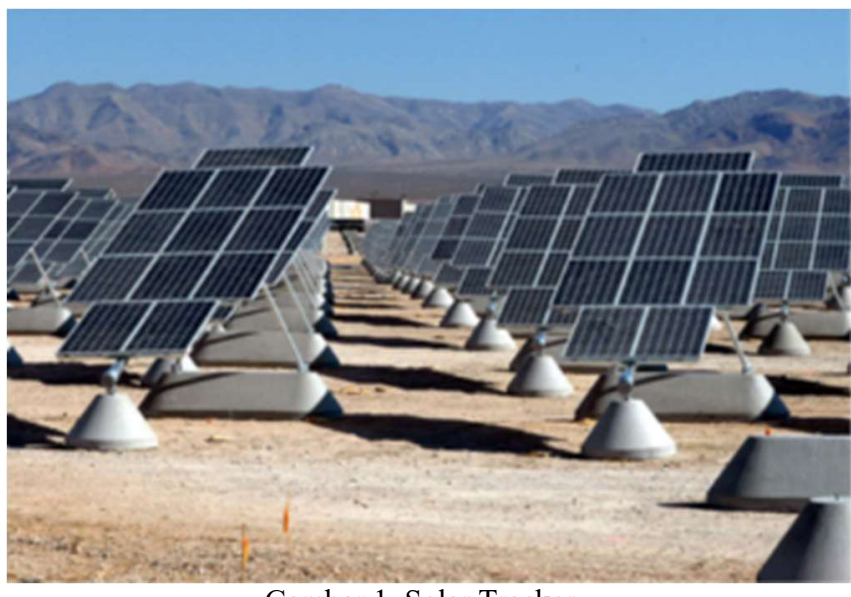

Gambar 1. Solar Tracker

Optik dalam aplikasi surya terkonsentrasi menerima komponen langsung cahaya matahari dan arena itu harus berorientasi tepat untuk mengumpulkan energi. Sistem pelacakan ditemukan di semua aplikasi konsentrator karena sistem tersebut tidak menghasilkan energi kecuali menunjuk matahari. Sinar matahari memiliki dua komponen, sinar matahari langsung yang membawa $90 \%$ energi. matahari dan sinar matahari menyebar yang membawa sisanya. Energi yang disumbangkan oleh sinar langsung menurun dengan cosinus dari sudut antara cahaya yang masuk dan panel[7]

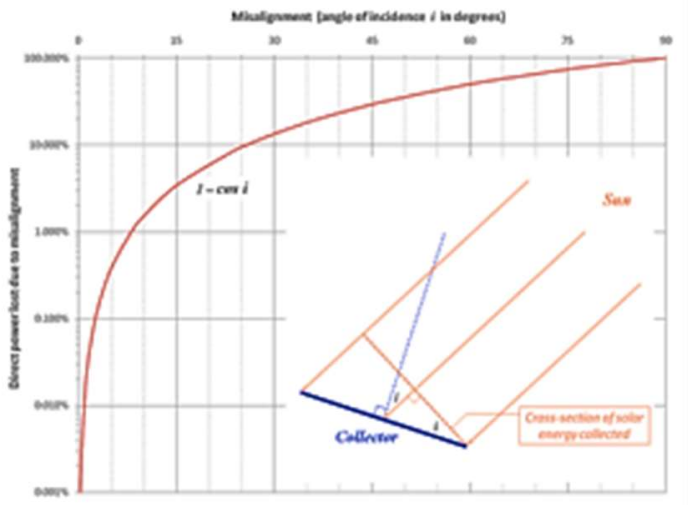

Gambar 2. Persentasi sinar matahari langsung yang hilang karena sudut

Ada beberapa jenis solar tracker, berdasarkan jumlah sumbunya dibagi menjadi single axis tracker (pelacak sumbu tunggal) dan dual axis tracker (pelacak sumbu ganda). Pelacak matahari dengan sumbu ganda dapat melakukan optimalisasi penyerapan cahaya yang lebih baik daripada pelacak sumbu tunggal. Gambar 3 adalah grafik yang menunjukkan perbandingan prosentase peningkatan energi dari beberapa sistem tracking terhadap panel surya tanpa tracking dan tilting (pemiringan) yang didasarkan pada studi rinci lebih dari 180 situs surya di Amerika Utara yang dilakukan oleh Dr. David Lubitz, Asisten Profesor Teknik di Universitas Guelph di Ontario.

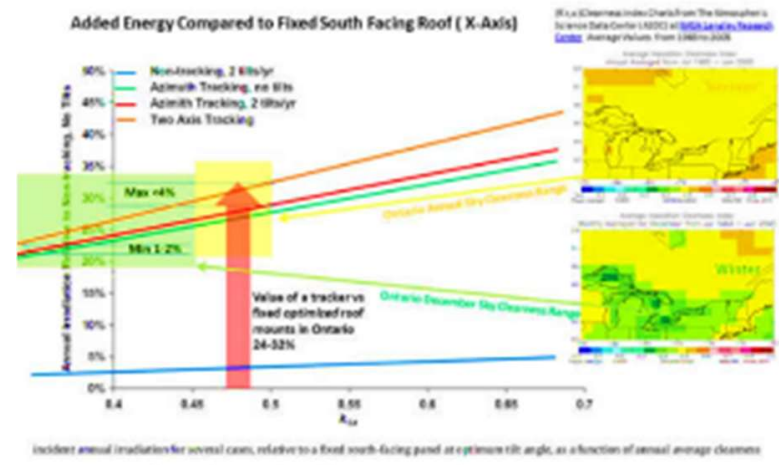

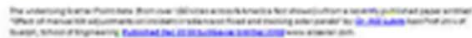

Gambar 3. Perbandingan peningkatan energi beberapa sistem tracking

Sumbu x menunjukkan nilai Sky Clearness Index, yaitu ukuran dari berapa banyak polusi dan faktor awan yang menyerap, merefleksikan, atau membiaskan cahaya mahatari. Kejelasan rendah adalah cahaya menyebar seperti hari kabur atau mendung. Sedangkan kejelasan tinggi di atas 0,7 atau 0,8 adalah hari yang sangat cerah dengan sedikit polusi di atmosfer. Ini adalah cahaya spekular seperti di daerah gurun dan khatulistiwa [7]

\section{METODE PENELITIAN}

Perancangan solar tracker dibuat berdasarkan bagan umum. Bagan umum pada penelitian ini berupa alur kerangka proses Solar Tracker untuk melacak posisi matahari. Dari bagan umum akan tampak mekanisme kerja solar tracker yang akan dirancang.

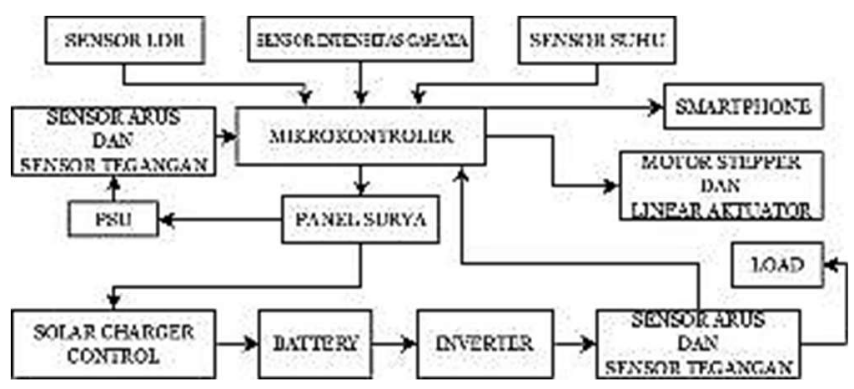

Gambar 4. Diagram alir sistem solar tracker 
Jurnal ECOTIPE, Vol. 7, No.2, Oktober 2020, Hal. 78-84

p-ISSN 2355-5068, e-ISSN 2622-4852

Akreditasi Kemenristekdikti (SINTA 4), SK. No.10/E/KPT/2019

DOI: 10.33019/jurnalecotipe.v7i2.1887

Pada gambar diatas menampilkan alir sistem kerja panel surya secara keseluruhan yang terhubung dengan seluruh komponen atau perangkat keras sehingga sistem dapat menggerakkan solar cell sesuai dengan yang diharapkan. Tampak bagaimana cara kerja solar tracker yang akan dirancang pada penelitian ini. Solar tracker yang akan dirancang pada penelitian ini menggunakan cahaya matahari sebagai input, $L D R$ sebagai sensor penjejak cahaya matahari, Mikrokontroller ATmega 2560 sebagai sistem kendali Stepper NEMA 23 dan Aktuator Linier sebagai output untuk menggerakkan solar panel dan Aplikasi Android pada smarthphone sebagai output monitoring dengan wi-fi sebagai media komunikasi antara aplikasi smarthphone dengan sistem kendali pada solar tracker.

Perancangan sistem pelacak matahari menggunakan prinsip kerja sensor cahaya LDR. Sensor yang akan mengirimkan sinyal ke mikrokontroller kemudian akan menggerakkan motor stepper NEMA23 dan linear Aktuator untuk memutar posisi panel surya agar mengikuti arah gerak dari sinar matahari. Energi surya yang diperoleh kemudian bisa langsumg di gunakan untuk beban yang arus nya telah diubah terlebih dahulu melalui inverter atau disimpan ke baterai untuk disimpan. Baterai menjadi perangkat yang dapat mengubah energi kimia langsung menjadi energi listrik

\section{A. Metode Pengumpulan data}

Pengujian peralatan Dual axis solar tracker (DAST) ini dilakukan di sekitar halaman rumah paada kondisi sinar matahari yang cerah sepanjang hari pada hari Sabtu 30 mei 2020 dari pukul 08.58 - 14.06 WIB. Pada interval waktu pengambilan data setiap 1 menit untuk mendapatkan data arus, tegangan, dan daya listrik. Metode yang digunakan dalam penelitian ini adalah uji eksperimental. Eksperimen dilakukan terhadap sistem mekanik dan dinamik kerangka dari dudukan panel surya. Sehingga metode pengontrolan panel surya mencapai yang diinginkan yaitu permukaan panel surya tegak lurus terhadap sinar matahari datang.

\section{B. Perancangan Alat}

Bagian ini membahas tentang desain dari Pembangkit Listrik Tenaga Surya Dengan menggunakan metode Dual Axis Solar Tracker
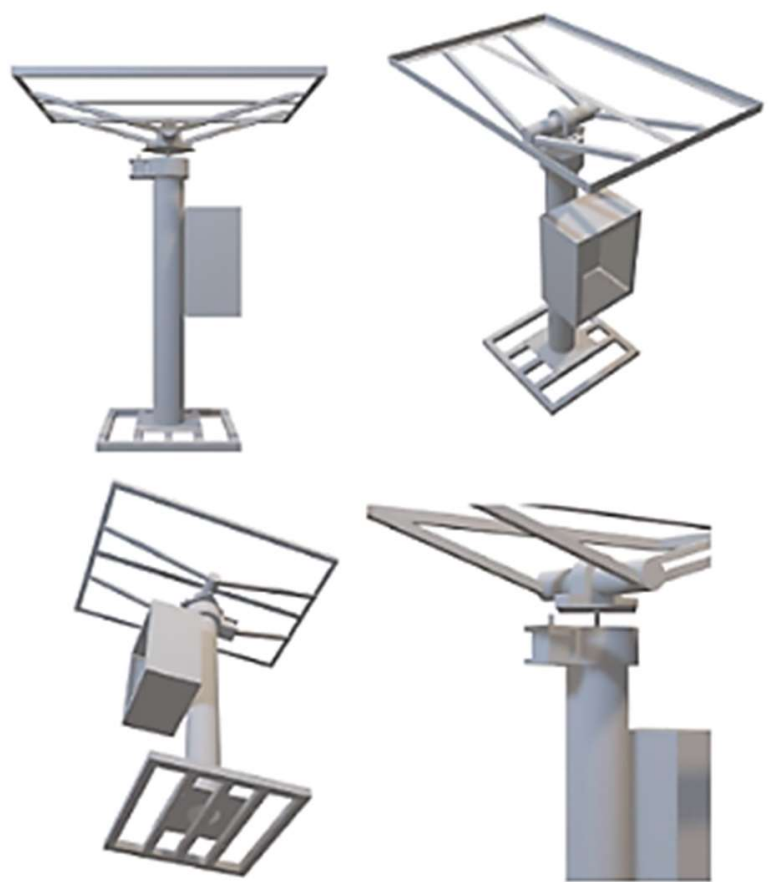

Gambar 3. Desain Dari Dual Axis Solar Tracker

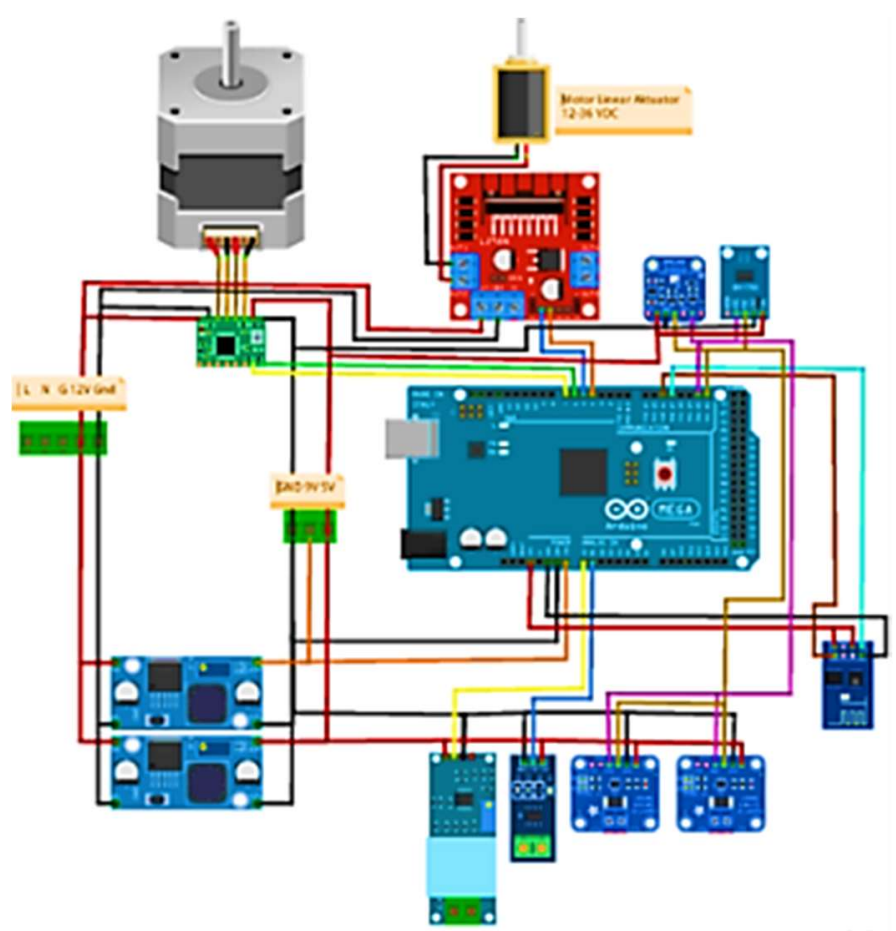

Gambar 4. Perancangan Sistem Dual Axis Solar Tracker 
Jurnal ECOTIPE, Vol. 7, No.2, Oktober 2020, Hal. 78-84

p-ISSN 2355-5068, e-ISSN 2622-4852

Akreditasi Kemenristekdikti (SINTA 4), SK. No.10/E/KPT/2019

DOI: 10.33019/jurnalecotipe.v7i2.1887

Desain alat atau produk ditampilkan pada gambar tersebut, dimana konsep dari alat bertinggi sekitar $1,5 \mathrm{M}$ dengan batang tiang penyangga modul surya menggunakan pipa besi berukuran panjang $1 \mathrm{M}$ dan tinggi dari penyangga panel surya sekitar $40 \mathrm{~cm}$. panel surya yang digunakan adalah jenis panel surya pollycristalyne $100 \mathrm{Wp}$. Dan dibutuhkan panel box sebagai tempat dari sistem kontrol, solar charge dan serial komunikasi. Komponen kontrol untuk menggerakkan modul surya menggunakan stepper NEMA23 sebagai gerakan memutar $360^{\circ}$ dan untuk pergerakan panel surya secara vertikal menggunakan aktuator linear sebagai penggerak nya. Penggunaan panel box adalah pelindung dari sebuah sistem karena sistem ditempatkan pada area outdor.
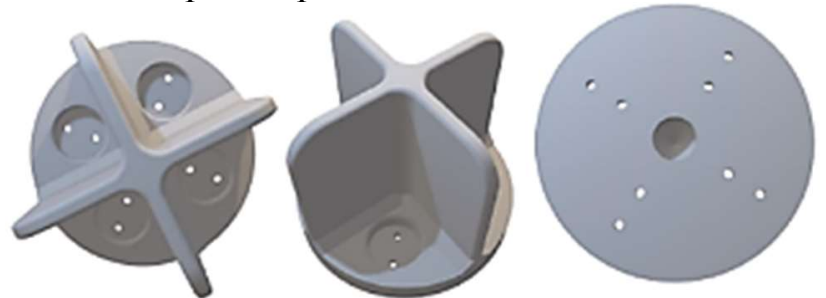

Gambar 4. Desain Peletakan Sensor LDR

Dalam pembacaan letak sebuah matahari digunakan pembagi bayangan dengan memanfatkan sinar sebuah matahari konsepnya serupa dengan jam matahari dimana menfaatkan sinar matahari dan melihat bayangan dari sebuah titik acuan. Pada gambar berikut adalah sebuah komponen untuk membaca letak matahari. Pembacaan matahari mengunakan sebuah sensor $L D R$ sebanyak 4 buah dan diletakan pada komponen yang sudah di tentukan. Komponen pembagi cahaya ini diletakan pada bagian ujung atas dari sebuah panel surya.

\section{HASIL PENELITIAN DAN PEMBAHASAN}

DAST (Dual Axis Solar Tracker) adalah cara terbaru yang dikembangkan oleh Pembangkit Listrik Tenaga Surya (PLTS) dalam jenis pemasangan nya. $D A S T$ adalah sistem penggerak yang bisa mengikuti gerakan matahari. Dengan cara ini PLTS akan menghasilkan energi lebih optimal. Sistem DAST juga dapat dikendalikan dan dimonitoring secara wireless. DAST (Dual Axis Solar Tracker) ini mengikuti posisi matahari melalui sensor cahaya Light Dependent Resistor (LDR).
Sistem Dual Axis Solar Tracker (DAST) menggunakan jenis modul panel surya Pollycristalyne $100 \mathrm{Wp}$, Arduino ATmega 2560, arduino ini Berfungsi sebagai pengendali seluruh sistem $D A S T$, dan sistem ini terdiri dari 4 buah sensor $L D R$ yang disekat menjadi beberapa ruangan. Perbandingan ke empat sensor tersebut terhadap besar intensitas cahaya yang mengenai sensor LDR akan digunakan untuk menggerakan motor untuk mengikuti posisi matahari dengan pergerakan searah jarum jam ataupun berlawanan dengan jarum jam, sampai ke empat sensor $L D R$ mendapat besar intensitas cahaya yang sama atau sinar matahari yang datang telah tegak lurus terhadap panel $S P V$. Berikut ini merupakan gambar dari sistem rancangan dari sistem $D A S T$ yang dapat dilihat pada gambar di bawah.

\section{A. Pengujian Alat}

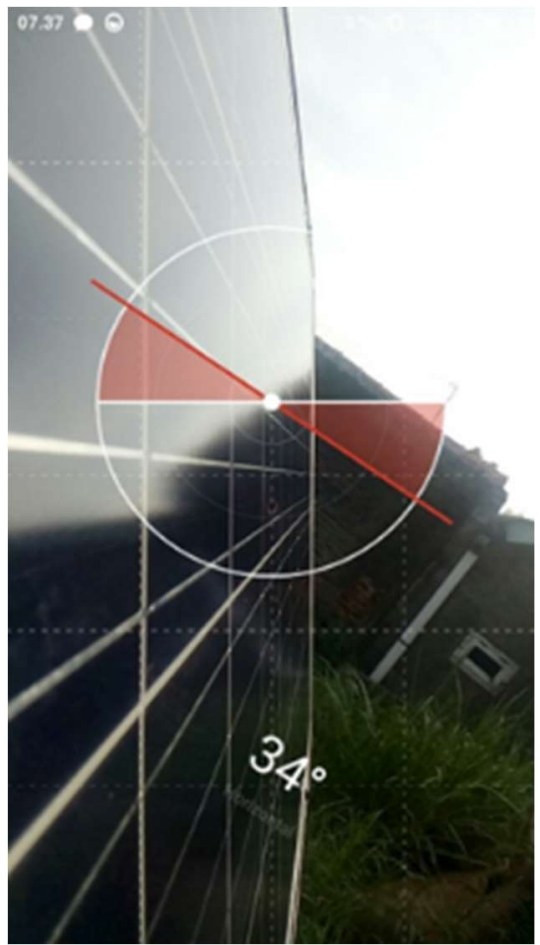

Gambar 7. Pengujian Sudut Sistem DAST

Pengambilan sampling data logger sensor dilakukan dengan jeda waktu 1 menit. Data didapatkan 308 sampling data dan dibentuk dalam grafik tampilan data. Sampling data dilakukan untuk mendapatkan nilai tegangan $P V$ tanpa beban, arus $P V$ tanpa beban, Suhu sekitar, dan intensitas cahaya. Hasil dari datalogger didapatkan nilai tertinggi PV 20,99 V DC dan terendah 
Jurnal ECOTIPE, Vol. 7, No.2, Oktober 2020, Hal. 78-84

p-ISSN 2355-5068, e-ISSN 2622-4852

Akreditasi Kemenristekdikti (SINTA 4), SK. No.10/E/KPT/2019

DOI: 10.33019/jurnalecotipe.v7i2.1887

19,75 V DC maka PV memiliki celah tegangan hingga $1,24 \mathrm{VDC}$.

Tabel 1. Nilai Data Keluaran Dual Axis Solar Tracker

\begin{tabular}{|l|c|c|c|c|}
\hline Nilai & $\begin{array}{c}\text { Tegangan } \\
(\mathrm{V})\end{array}$ & $\begin{array}{c}\text { Arus } \\
(\mathrm{mA})\end{array}$ & $\begin{array}{c}\text { Suhu } \\
\left({ }^{0} \mathrm{C}\right)\end{array}$ & $\begin{array}{c}\text { Intensitas } \\
\text { Cahaya (lux) }\end{array}$ \\
\hline Max & 20,99 & 21,04 & 46,12 & 50913,81 \\
\hline Min & 19,75 & 14,12 & 32,95 & 30154,84 \\
\hline
\end{tabular}

B. Grafik Pengujian Dual Axis Solar Tracker

Hasil dari pengambilan data telah diolah dengan menggunakan Microsoft Excel sehingga menghasilkan grafik sample selama masa pengambilan data, seperti yang terlihat pada gambar 7

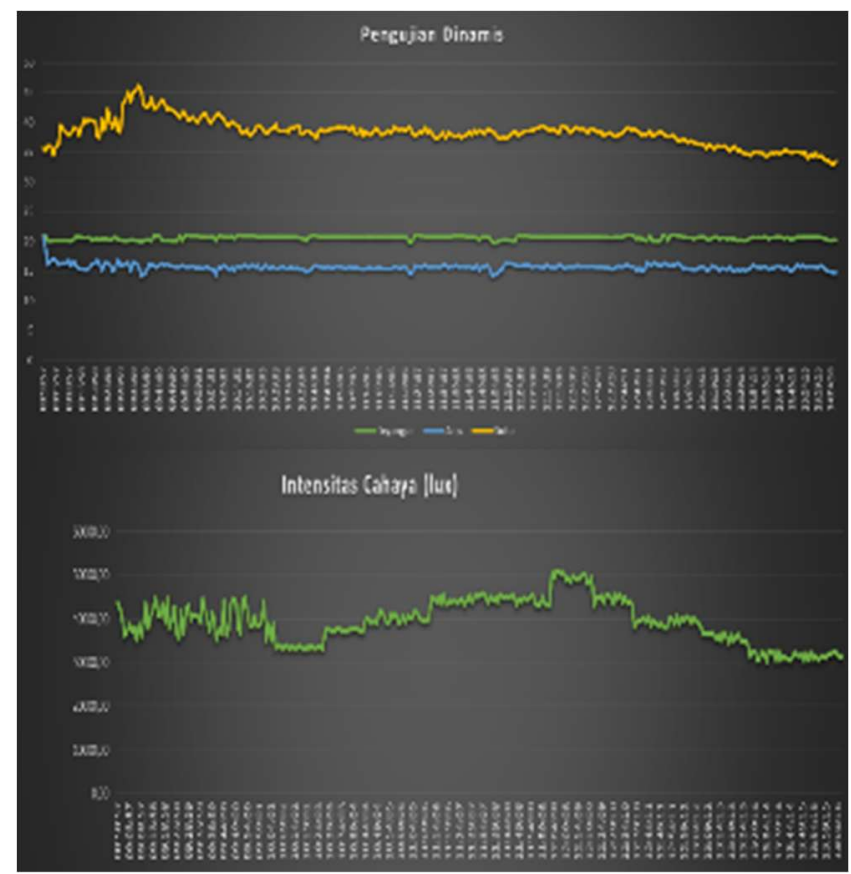

Gambar 7. Grafik hasil Dual Axis Solar Tracker

Dari gambar dapat diketahui bahwa pengujian $D A S T$ dapat dilakukan dengan sesuai apa yang diharapkan di awal melakukan perancangan. Karena sistem DAST dapat bekerja selalu berusaha mengikuti arah matahari teroptimal yaitu pada pagi hari kearah timur dan selalu mengikuti pergerakan matahari sampai pada waktu sore hari menuju kearah barat.

Produksi energi matahari yang dihasilkan dengan menggunakan sistem Dual Axis Solar Tracker Dengan nilai tertinggi $P V 20,99$ Volt dan terendah 19,75 Volt

\section{Grafik Pengujian Posisi Statis}

Tabel 2. Nilai Data Keluaran Posisi Panel Surya Tetap (Statis)

\begin{tabular}{|l|c|c|c|c|}
\hline Nilai & $\begin{array}{c}\text { Tegangan } \\
(\mathrm{V})\end{array}$ & $\begin{array}{c}\text { Arus } \\
(\mathrm{mA})\end{array}$ & $\begin{array}{c}\text { Suhu } \\
\left({ }^{0} \mathrm{C}\right)\end{array}$ & $\begin{array}{c}\text { Intensitas } \\
\text { Cahaya (lux) }\end{array}$ \\
\hline Max & 19,99 & 18,3 & 46,12 & 54612,5 \\
\hline Min & 18,6 & 13,72 & 32,95 & 6235,83 \\
\hline
\end{tabular}

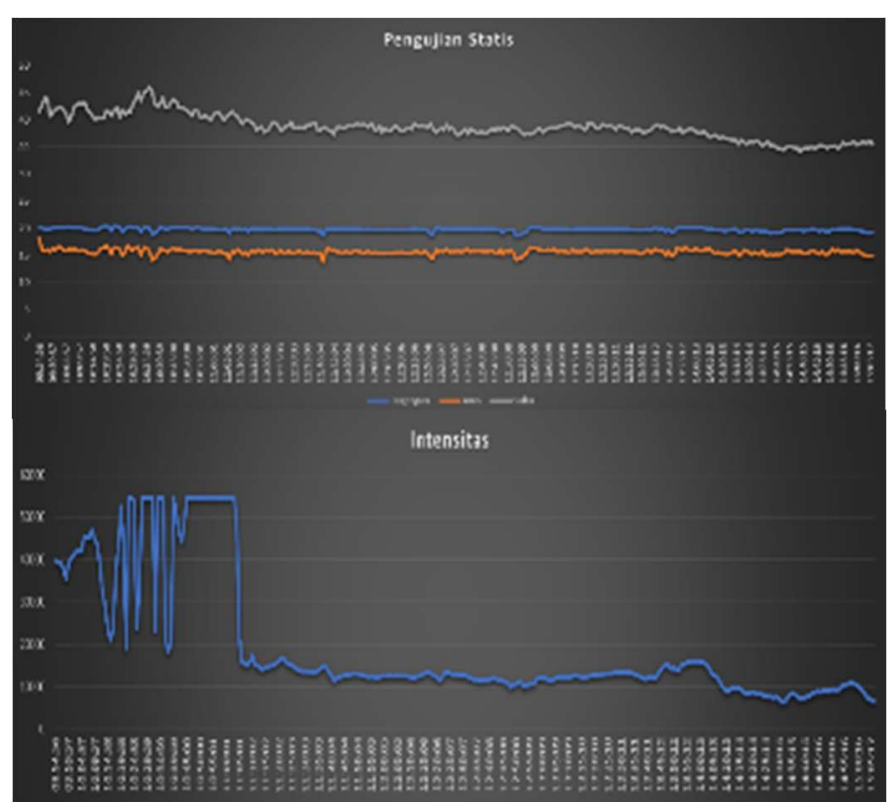

Gambar 8. Grafik Hasil Panel Surya Posisi Statis

\section{KESIMPULAN}

Secara keseluruhan sistem Dual Axis Solar Tracker (DAST) yang telah dirancang dan dibangun dapat bekerja dengan baik, yaitu mampu menggerakan solar panel mengikut posisi matahari sehingga sinar matahari yang datang tegak lurus terhadap permukan panel Solar Photovoltaic (SPV). Panel SPV dengan sistem DAST mampu menghasilkan produksi energi yang lebih optimal karena mingikuti pergerakan matahari dengan perolehan nilai tegangan maksimal 20,99 volt dan minimal di tegangan 19,75 volt serta arus maksimal yang dihasilkan 21,04 mA dan minimal $14,12 \mathrm{~mA}$, Sementara itu untuk pengujian panel surya dengan posisi tetap (statis) di dapatkan tegangan maksimum yang dihasilkan panel surya sebesar 19,99 Volt dan minimum 18,3 Volt serta arus maksimum sebesar 18,3 mA dan minimum 13,72 mA.

Sensor $L D R$ dapat digunakan untuk mengarahkan arah suatu objek tepat ke arah sudut datangnya matahari dengan menggunakan Mikrokontroller 
Jurnal ECOTIPE, Vol. 7, No.2, Oktober 2020, Hal. 78-84

p-ISSN 2355-5068, e-ISSN 2622-4852

Akreditasi Kemenristekdikti (SINTA 4), SK. No.10/E/KPT/2019

DOI: 10.33019/jurnalecotipe.v7i2.1887

ATmega 2560 sebagai pengendali sistem dan motor (stepper NEMA23 dan Linear Aktuator) sebagai penggerak pada dua sumbu ( $\mathrm{x}$ dan $\mathrm{y}$ ) sehingga menghsilkan keakuratan yang cukup baik.

\section{DAFTAR PUSTAKA}

[1] M. W. Ardiatama and I. Abadi, "Perancangan Sistem Penjejak Matahari Dua Sumbu Dengan Metode Active Tracking Menggunakan Kontrol Fuzzy Tipe-2 Interval," J. Tek. ITS, vol. 7, no. 1, pp. B78-B83, 2018.

[2] M. Bachtiar, "Prosedur perancangan sistem pembangkit listrik tenaga surya untuk perumahan (solar home system)," SMARTek, vol. 4, no. 3, pp. 176-182, 2016.

[3] Kementrian ESDM, "Konsumsi Listrik Nasional," Katadata, 2018.

[4] R. G. Vieira, F. Guerra, M. Vale, and M. M. Araújo, "Comparative performance analysis between static solar panels and single-axis tracking system on a hot climate region near to the equator," Renew. Sustain. Energy Rev., vol. 64, pp. 672-681, 2016.

[5] B. Lane, "Solar tracker," EEC, vol. 517, 2008.

[6] Y. J. Huang, T. C. Kuo, C. Y. Chen, C. Chang, P. $\mathrm{Wu}$, and $\mathrm{T}$. $\mathrm{Wu}$, "The design and implementation of a solar tracking generating power system," Eng Lett, vol. 17, no. 4, pp. 1-5, 2009.

[7] S. K. Nisa, "PROTOTIPE DUAL AXIS SUN TRACKER DENGAN SENSOR,” 2013. 